\title{
KORELASI TINGKAT PENGGUNAAN SMARTPHONE DENGAN TINGKAT KECEMASAN PESERTA DIKLAT PUSDIKLAT TENAGA TEKNIS PENDIDIKAN DAN KEAGAMAAN
}

\author{
Nuraini $^{1}$ \\ ${ }^{1}$ Badan Litbang dan Diklat Kementerian Agama \\ ${ }^{1}$ ainikafa11@gmail.com
}

https://doi.org/10.36052/andragogi.v9i1.191

Diterima: 8 Januari 2021 | Disetujui: 29 Mei | Dipublikasikan: 30 Juni 2021

\begin{abstract}
Abstrak
Tujuan penelitian ini adalah untuk mengetahui hubungan antara penggunaan smartphone dengan kecemasan peserta diklat, tingkat penggunaan smartphone peserta diklat dan tingkat kecemasan peserta diklat. Metode penelitian ini dengan mengunakan survei dengan responden peserta diklat di Pusdiklat Tenaga Teknis Pendidikan dan Keagamaan sebanyak 106 orang. Hasil penelitian diperoleh ada hubungan positif yang sangat signifikan antara penggunaan smartphone dengan kecemasan peserta diklat. Artinya makin tinggi instensitas penggunaan smartphone maka akan makin tinggi pula tingkat kecemasannya, demikian sebaliknya semakin rendah intensitas penggunaan smartphone akan semakin rendah juga tingkat kecemasannya. Untuk tingkat penggunaan smartphone sebagian besar peserta diklat termasuk kategori penggunaan smartphone pada tingkat sedang yaitu dengan persentase $52 \%$ (55 orang) kemudian $16 \%$ (17 orang) peserta diklat memiliki tingkat penggunaan smartphone pada kategori tinggi dan 32\% (34 orang) peserta memiliki tingkat penggunaan smartphone pada taraf yang rendah. Hasil penelitian untuk tingkat kecemasan menunjukkan bahwa 50 orang (47\%) peserta diklat memiliki kecemasan pada tingkat sedang, 34 orang $(32 \%)$ responen memiliki tingkat kecemasan pada kategori tinggi, sedangkan 22 orang $(21 \%)$ peserta diklat memiliki tingkat kecemasan pada taraf yang rendah. Semakin banyak fitur dalam smartphone yang bisa digunakan dalam kehidupan sehari-hari penggunanya maka akan menyebabkan ketergantungan yang tinggi terhadap smartphone yang pada akhirnya akan menyebabkan semakin tinggi tingkat kecemasan penggunanya. Kecemasan saat smartphone jauh dari penggunanya terjadi karena mereka tidak bisa melakukan kontak apapun dengan orang lain (keluarga dan teman) atau berinteraksi lewat smartphonenya, mengakses sosial media, mengakses informasi, bahkan untuk saat ini intensitas penggunaan smartphone semakin meningkat karena aplikasi yang mempermudah hidup seperti transportasi online, mobile banking sehingga ketiadaan smartphone akan semakin meningkatkan kecemasan penggunanya.
\end{abstract}

Kata Kunci: penggunaan smartphone, kecemasan, diklat

\begin{abstract}
CORRELATION OF SMARTPHONE USE LEVEL WITH AN ANXIETY LEVEL OF TRAINING PARTICIPANTS. The purpose of this study is to determine the relationship between smartphone use and participants' anxiety of education and training program (Diklat/ Pendidikan dan Pelatihan), the level of smartphone use of Diklat's participants, and the anxiety level of Diklat's participants. This research method uses a survey with 106 training participants in the Education and Religious Technical Training Center as many as 106 people. The results of this study show that there is a very positive relationship between smartphone use and participants' anxiety of Diklat. So, the higher the intensity of smartphone use, the higher the anxiety level, and vice versa the lower the intensity of smartphone use, the lower the anxiety level. Regarding the level of smartphone use of Diklat's participants, 52\% (55 people) were included in moderate level, 16\% (17 people) were considered high level smartphone users and 32\% (34 people) of the participants were low level users. Then, the results of the study for anxiety levels showed that 50 people (47\%) of the participants had anxiety at a moderate level, 34 people (32\%) had high level anxiety, and 22 people (21\%) had low level anxiety. The more often the smartphone used by them in daily life, the higher the level of anxiety experienced by them if they do not have access to their smartphone. Anxiety arises because they cannot send messages, browse, or make a call to people (such as family and friends). Even, the intensity of using smartphone is increasing now as there are many mobile applications that provide facilities for human life such as online transportation and mobile banking so that the absence of smartphones will increase anxiety.
\end{abstract}

Keywords: anxiety, education and training, smartphone 


\section{PENDAHULUAN}

P roliferasi smartphone telah membawa komputasi mobile kepada massa. Dengan smartphone, kita dapat dengan mudah dan cepat mendapatkan setiap informasi tanpa terbatas runag dan waktu. Laporan Newzoo menunjukkan bahwa Indonesia menempati posisi keempat pengguna ponsel pintar (smartphone) terbesar di dunia dengan 160,23 juta pengguna. Penetrasi smartphone di dalam negeri telah mencapai $58,6 \%$ dari total populasi (https://databoks.katadata.co.id, 2021). Menurut laporan terbaru yang dirilis oleh layanan manajemen konten HootSuite, dan agensi pemasaran media sosial We Are Social dalam laporan bertajuk "Digital 2021", bahwa smartphone menjadi perangkat yang paling populer pengguna internet untuk mengakses internet. Pengguna internet Indonesia (usia 16 hingga 64 tahun) yang memiliki telepon genggam adalah 98,3 persen. Tercatat ada 96,4 persen atau 195,3 juta orang Indonesia yang mengakses di internet melalu ponsel genggamnya. Pengguna internet di Indonesia pada awal 2021 mencapai 202,6 juta jiwa. Jumlah ini meningkat 15,5 persen atau 27 juta jiwa jika dibandingkan pada Januari 2020. Total jumlah penduduk Indonesia sendiri saat ini adalah 274,9 juta jiwa. Ini artinya, penetrasi internet di Indonesia pada awal 2021 mencapai 73,7 persen (https://tekno.kompas.com ,2021).

Dilasir dari websindo.com pada Januari 2019 total Penduduk Indonesia mencapai 268,2 juta jiwa, sementara diketahui pengguna mobile (ponsel pintar dan tablet) mencapai 355,5 juta. Artinya peredaran ponsel pintar dan tablet lebih banyak dari jumlah penduduk di seluruh Indonesia. Bisa terjadi jika satu orang memiliki 2 atau lebih gawai (gadget) (https://websindo.com/indonesia-digital2019-tinjauan-umum/ ).

Dengan aplikasi yang melimpah, smartphone memberi pengguna komunikasi berbasis internet, perdagangan bisnis, pendidikan, media hiburan, dan bahkan aplikasi klinis. Dengan variasi fungsi dan kemudahan penggunaan, jumlah pengguna global yang diperkirakan lebih dari 1,08 miliar pada awal 2012, dan meningkat dengan kecepatan tinggi. Namun, smartphone bisa bermasalah jika digunakan secara berlebihan. Rata-rata pengguna smartphone di dunia akan membuka atau mengecek smartphonenya setiap 12 menit sekali. Hal ini sebanding dengan melakukan kegiatan berputar-putar sebanyak 80 kali dalam sehari. (Haug et.al, 2015). Orang Indonesia menghabiskan waktu lebih dari 3-4 jam untuk mengakses internet setiap harinya (Agus Tri Haryanto, 2018)

Penggunaan secara berlebihan karena kemudahan dan kenyamanan dari fitur-fitur yang ditawarkan smartphone, dapat menimbulkan masalah salah satunya adalah nomophobia yang akhir-akhir ini sedang menjadi perhatian seluruh dunia. Nomophobia digambarkan sebagai ketakutan dikarenakan individu berjauhan dari smartphone atau internetnya, nomophobia juga diartikan sebagai perasaan cemas dikarenakan tidak tersedianya perangkat seperti komputer atau perangkat komunikasi virtual lainnya (King et.al., 2014).

Nomophobia atau dikenal dengan singkatan "No Mobile Phone Phobia" atau penyakit yang tidak bisa jauh dari mobile phone. Suatu penyakit ketergantungan yang dialami seseorang terhadap mobile phone, sehingga bisa mendatangkan kekhawatiran atau kecemasan yang berlebihan jika tidak didampingi oleh mobile phone nya. Individu yang lebih banyak menghabiskan waktu dengan mobile phonenya dibandingkan berinteraksi dengan orang-orang disekitarnya bisa didiagnosis atau dikategorikan menderita Nomophobia (Kendler dalam Davidson, dkk., 2006: 185). Nomophobia diartikan dengan "ketakutan yang muncul disebabkan tidak bisa jauh dari mobile phone". Istilah Nomophobia pertama kali dicetuskan pada saat penelitian yang dilakukan oleh Kantor Pos Inggris tahun 2008 untuk menyelidiki tingkat kecemasan penderita pengguna mobile phone. Istilah lain untuk merujuk orang-orang dengan nomophobia, yaitu nomophobe dan nomophobic yang merupakan istilah lain yang diperkenalkan dan digunakan bahasa sehari-hari (Mahenda, 2013:6).

Seseorang yang diagnosis menderita nomophobia dicirikan dengan perilaku kecemasan yang berlebihan seperti, tidak sanggup menon-aktifkan ponselnya untuk beberapa waktu, memiliki rasa khawatir yang berlebihan jika daya baterai ponselmya habis, 
terus-menerus membuka ponselnya walaupun hanya sekedar memeriksa pesan, panggilan, email baru dan sosial media. Bahkan mereka akan membawa ponselnya hingga ke kamar mandi karena terlalu cemas jika ponselnya juah dari jangkauannya.

Selain istilah Nomophobia dikenal juga istilah Fear of Missing Out (FoM0) yaitu adanya keinginan yang besar untuk tetap terus terhubung dengan apa yang sedang dilakukan oleh orang lain melalui dunia maya (Przybylsky, 2013). FoM0 di definisikan juga sebagai perasaan gelisah dan takut bahwa seseorang tertinggal, apabila teman-temannya sedang melakukan atau merasakan sesuatu yang lebih baik atau lebih menyenangkan dibanding apa yang sedang ia lakukan atau ia miliki saat ini. Perasaan di mana seseorang merasa begitu khawatir jika melewatkan tren yang sedang terjadi dikehidupan sosialnya.

Orang yang menderita gangguan kecemasan sosial ini, mengalami perasaan rendah diri, penghinaan dan depresi karena takut dihakimi oleh orang lain. hasil studi yang dilakukan pada Februari-Mei 2017 oleh RSPH (Royal Society of Public Health), yaitu sebuah lembaga independen untuk kesehatan masyarakat di Britania Raya, Inggris yang menyatakan bahwa survei tersebut menyebutkan ada sekitar $40 \%$ pengguna media sosial mengidap penyakit FoM0. FoMo telah diteliti secara mendalam dan dipublikasikan di jurnal Computers in Human Behaviour pada 2013 lalu, dari hasil penelitian yang dilakukan pada saat itu menunjukkan bahwa sampel objek di bawah usia 30 tahun memiliki kecenderungan tertinggi mengalami FoM0. Selain itu, uniknya perempuan disebut lebih banyak mengalami FoM0 daripada laki-laki. Hasil Survei FoMO yang dilakukan oleh organisasi profesi psikologi Australia (Australian Psychological Society) atau disingkat APS menunjukkan bahwa remaja rata-rata 2,7 jam per hari. Prevalensi FoM0 pada remaja adalah $50 \%$, sedangkan pada kelompok dewasa adalah $25 \%$. Penelitian ini juga menemukan bahwa, remaja secara signifikan lebih besar kemungkinannya mengalami fenomena FoMo dibandingkan kelompok dewasa. Artinya, media sosial sangat berpengaruh pada remaja dalam pembentukan identitas diri.
Penelitian tentang kecemasan yang diakibatkan karena penggunaan smartphone telah banyak dilakukan khususnya dikalangan remaja (usia dibawah 30 tahun). Sementara untuk yang usia dewasa belum banyak ditemukan hasil penelitiannya, khususnya untuk peserta pendidikan dan pelatihan (diklat).

Pendidikan dan Pelatihan (diklat) yang di selenggarakan oleh Pusdiklat Tenaga Teknis Pendidikan dan Keagamaan memiliki jadwal kegiatan yang padat, pembelajaran mulai dari pukul 07.30 WIB berakhir sekitar pukul 18.00 WIB bahkan kadang ada pembelajaran malam yang berakhir sekitar pukul 21.30 WIB. Dan smartphone dengan aplikasi Whatsapp (WA) nya menjadi sarana komunikasi yang paling diminati dan efektif untuk berbagi informasi, baik informasi terkait perubahan jadwal maupun berbagi atau share materi bahkan tugas-tugas. Pentingnya peran smartphone dalam kegiatan kediklatan menjadi dilema buat penyelenggara, karena dari hasil observasi awal penulis, panitia sepertinya kesulitan untuk melarang peserta bermain dengan smartphonenya saat proses pembelajaran. Terutama saat proses pembelajaran kurang interkatif atau cenderung membosankan, peserta akan saling share fotofoto atau joke-joke lewat WAG (Whatsapp Group).

Tujuan dari penelitian ini adalah untuk mengetahui hubungan antara penggunaan smartphone dengan kecemasan pada peserta diklat, mengetahui tingkat penggunaan smartphone pada peserta diklat, dan untuk mengetahui tingkat kecemasan pada peserta diklat di Pusdiklat Tenaga Teknis Pendidikan dan Keagamaan.

\section{METODE PENELITIAN}

Metode yang digunakan dalam penelitian adalah metode survei. Variabel bebas dalam penelitian adalah penggunaan smartphone dan variabel terikat adalah kecemasan. Sampel penelitian sebanyak 106 orang yang diambil secara acak dari peserta diklat yang diselenggarakan pada tanggal 18 sd 24 maret 2019 ada 4 diklat teknis substantif yaitu teknis substantif agribisnis bagi guru pondok pesantren, perkoperasian bagi guru pondok pesantren, teknis substantif pentashih mushaf 
alquran dan tadqiq/penilaian buku pendidikan agama. Karakteristik responden secara lengkap dapat dilihat pada Tabel 1.

Tabel 1. Distribusi frekuensi karakteristik responden

\begin{tabular}{cccc}
\hline Karakteristik & Katagori & Frekuensi & Persentase \\
\hline Jenis kelamin & Laki-Laki & 84 & 79,25 \\
& Perempuan & 22 & 20,75 \\
Usia & $20-30$ thn & 24 & 22,64 \\
& $31-40$ thn & 28 & 26,42 \\
& $41-50$ thn & 44 & 41,51 \\
Tingkat & $51-60$ thn & 10 & 9,43 \\
pendidikan & SMA & 19 & 17,92 \\
& S1 & 57 & 53,77 \\
& S2 & 26 & 24,53 \\
& S3 & 4 & 3,77 \\
\hline
\end{tabular}

Sumber: Olah Data Penulis, 2019

Instrumen penggunaan smartphone terdiri dari 5 item yaitu jumlah smartphone, durasi penggunaan, banyaknya menggunakan smartphone dalam satu hari, jarak waktu penggunaan smartphone dan aktivitas terbanyak dari penggunaan smartphone, sedangkan untuk kecemasan bentuk skala likert dengan indikator kecemasan yang diambil dari (Gail W. Stuart 2006: 149) yaitu aspek afektif yang terdiri dari mudah terganggu, tidak sabar, gelisah, gugup, ketakutan kecemasan dan merasa malu atau di pede saat berjauhan dari smartphonenya, yang dijabarkan menjadi 15 item dengan sub indikator yaitu mudah terganggu, tidak sabar, gelisah, gugup, ketakutan kecemasan dan merasa malu saat berjauhan dari smartphonenya. Hasil uji validitas menunjukkan bahwa seluruh item instrumen valid dan reliabilbel dengan Cronbach's Alpha di atas 0,6, yaitu 0,892 .

\section{TEMUAN DAN PEMBAHASAN}

\section{Temuan}

\section{Tingkat Penggunaan Smartphone Peserta Diklat}

Instrumen penggunaan smartphone terdiri dari 5 item yaitu jumlah smartphone, durasi penggunaan, banyaknya menggunakan smartphone dalam satu hari, jarak waktu penggunaan smartphone dan aktivitas terbanyak dari penggunaan smartphone dengan hasil seperti pada tabel 2 .

Pada tabel 2 terlihat bahwa 91 orang $(85,85 \%)$ responden memiliki 1 buah smartphone dan tidak ada responden yang memiliki lebih dari 2 buah smartphone. 1-3 jam merupakan durasi penggunaan smartphone terbanyak dalam 1 hari dengan jumlah responden 34 orang atau sekitar 32,08\%. Temuan ini sejalan dengan hasil riset Hootsuite yang melaporkan bahwa pengguna aktif layanan internet menghabiskan waktu 3 jam 14 menit untuk mengakses internet (Kompas.com 23/02/2021)

Banyaknya penggunaan smartphone dalam satu hari terbanyak yaitu 53 orang responden (50\%) pada katagori 6-10 kali/perhari. Waktu 6-30 menit jarak waktu terbanyak menurut 30 orang responden $(35,85 \%)$ penggunaan smartphone dari mulai bangun tidur. Sedangkan untuk aktivitas terbanyak dari penggunaan smartphone adalah untuk sosial media sebanyak 64 orang $(60,38 \%)$. Hasil laporan Hootsuite juga menuliskan bahwa ada 170 juta jiwa orang Indonesia yang merupakan pengguna aktif media sosial. Dan 98,3\% pengguna internet di Indonesia yang memiliki telepon genggam itu dengan rentang usia 16 hingga 64 tahun (Kompas.com - 23/02/2021). 
Tabel 2. Distribusi frekuensi penggunaan smartphone

\begin{tabular}{|c|c|c|c|}
\hline Karakteristik & Kategori & Frekuensi & Persentase \\
\hline \multirow{3}{*}{ Jumlah smartphone } & 1 buah & 91 & 85,85 \\
\hline & 2 buah & 15 & 14,15 \\
\hline & lebih dari 2 buah & 0 & - \\
\hline \multirow[t]{6}{*}{ Durasi Penggunaan dalam 1 hari } & $<10$ menit & 8 & 7,55 \\
\hline & $11-60$ menit & 28 & 26,42 \\
\hline & 1-3 jam & 34 & 32,08 \\
\hline & 3-5 jam & 20 & 18,87 \\
\hline & 5-6 jam & 4 & 3,77 \\
\hline & $>6$ jam & 12 & 11,32 \\
\hline \multirow{6}{*}{$\begin{array}{l}\text { Banyaknya penggunaan } \\
\text { smartphone dlm satu hari }\end{array}$} & $<5 \mathrm{kali} / \mathrm{hari}$ & 15 & 14,15 \\
\hline & 6-10 kali/hari & 53 & 50,00 \\
\hline & 11-20 kali/hari & 20 & 18,87 \\
\hline & 21-50 kali/hari & 11 & 10,38 \\
\hline & 51-100 kali/hari & 4 & 3,77 \\
\hline & > 100 kali/hari & 3 & 2,83 \\
\hline \multirow{4}{*}{$\begin{array}{l}\text { Jarak waktu penggunaan } \\
\text { smartphone }\end{array}$} & 5 menit & 26 & 24,53 \\
\hline & 6-30 menit & 38 & 35,85 \\
\hline & 31-60 menit & 20 & 18,87 \\
\hline & setelah lebih dari 60 menit & 22 & 20,75 \\
\hline \multirow{4}{*}{$\begin{array}{l}\text { Aktivitas terbanyak dari } \\
\text { penggunaan smartphone }\end{array}$} & internet browsing & 18 & 16,98 \\
\hline & sosial media & 64 & 60,38 \\
\hline & telepon & 22 & 20,75 \\
\hline & main games & 2 & 1,89 \\
\hline
\end{tabular}

Sumber: Olah Data Penulis, 2019

\section{Pengujian kelayakan model regresi}

Pengujian menggunakan analisis varians (uji-F) bertujuan untuk mengetahui apakah model persamaan regresi dapat digunakan untuk membuat kesimpulan atau apakah persamaan regresi yang diperoleh signifikan atau tidak. Persamaan regresi $\hat{Y}=11,501+1,927 \mathrm{X}$ dapat digunakan untuk menjelaskan dan mengambil kesimpulan lebih lanjut tentang hubungan antara penggunaan smartphone dengan kecemasan karena regresi sangat signifikat dengan $F_{\text {hitung }}=44,953>F_{\text {tabel }}=6,90$. Berdasarkan hasil uji anova diperoleh tingkat signifikansi $(p$-value $)<a(0.000<0.05)$, maka penelitian ini layak untuk diuji menggunakan model regresi karena variabel intensitas penggunaan smartphone memiliki indikasi dapat mempengaruhi variabel kecemasan dalam penelitian ini.

\section{Koefisien determinasi}

Koefisien determinasi pada regresi linear sering diartikan sebagai seberapa besar kemampuan variabel bebas dalam menjelaskan varians dari variabel terikatnya. Dengan kata lain, nilai koefisien determinasi ini berguna untuk memprediksi dan melihat seberapa besar kontibusi pengaruh yang diberikan variabel $X$ secara simultan (bersama-sama) terhadap variabel $Y$.

Tabel 3. Hasil perhitungan koefisien determinasi

\section{Model Summary}

\begin{tabular}{|c|c|r|r|r|}
\hline Model & $R$ & $R$ Square & $\begin{array}{r}\text { Adjusted R } \\
\text { Square }\end{array}$ & $\begin{array}{r}\text { Std. Error of } \\
\text { the Estimate }\end{array}$ \\
\hline 1 & $0,549^{\mathrm{a}}$ & 0,302 & 0,295 & 6,84660 \\
\hline
\end{tabular}

a. Predictors: (Constant), Penggunaan_Smartphone

b. Dependent Variable: Kecemasan 
Pada tabel 3 diketahui nilai $\mathrm{r}^{2}$ atau $\mathrm{R}$ Square yaitu 0,302. Jadi dapat diketahui bahwa skor koefisien determinasi dalam penelitian ini adalah 30,2\%. Angka tersebut menjelaskan bahwa variabel kecemasan hanya dipengaruhi sebesar $30,2 \%$ oleh variabel penggunaan smartphone. Sedangkan sebanyak 69,8\% lainnya dipengaruhi oleh variabel-variabel lain yang tidak diteliti dalam penelitian ini.

Berdasarkan tabel 3 dapat dilihat pula nilai SEE (Std. Eror of the Estimate) yaitu 6,846 . Nilai tersebut lebih kecil daripada standar deviasi untuk variabel kriterion, yaitu 9.324 dalam tabel. Maka dari itu, karena nilai SEE < STD $(6,846<9,324)$, maka model regresi sudah baik dan dapat digunakan sebagai prediktor. Semakin kecil nilai SEE akan membuat model regresi semakin tepat untuk memprediksi variabel kriterion.

\section{Perhitungan koefisien regresi}

Bagian koefisien regresi menggambarkan persamaan regresi untuk mengetahui angka konstan dan uji hipotesis signifikansi koefisien regresi. Maka diketahui jika p- value .000 sedangkan koefisien a yang ditentukan yaitu .05 yang artinya $p$-value $<a(.000<.05)$ atau memenuhi syarat untuk menolak $\mathrm{HO}$ dan menerima $\mathrm{H} 1$ yang berarti terdapat hubungan positif antara penggunaan smartphone dengan kecemasan peserta diklat Pusdiklat Tenaga Teknis Pendidikan dan Keagamaan.

Dalam penelitian ini juga diketahui bahwa persamaan regresi yang diperoleh yaitu $\hat{Y}=11,501+1,927 X$ yang artinya, setiap penambahan 1 pada variabel penggunaan smartphone, maka kecemasan akan meningkat sebesar 1,927 . Sehingga dapat dikatakan bahwa semakin tinggi intensitas penggunaan smartphone maka akan semakin tinggi pula kecemasan peserta diklat.

\section{Deskripsi Data Hasil Penelitian}

Selain meneliti tentang hubungan kausalitas antara dua variabel, dalam penelitian ini juga dilakukan analisa terhadap gambaran variabel penggunaan smartphone pada peserta diklat di Pusdiklat Tenaga Teknis Pendidikan dan Keagamaan secara empiris. Berdasarkan hasil perhitungan untuk penggunaan smartphone maka diketahui bahwa rata-rata (mean) $=11,73$ dan median 11 dengan nilai minimum 7 serta nilai maksimum 18 . Sedangkan rentang dalam penelitian ini adalah 11 . Berdasarkan nilai rentang tersebut, maka peneliti mengategorikan penggunaan smartphone menjadi tiga kategori yaitu: tinggi, sedang, dan rendah.

Peserta diklat yang memiliki tingkat penggunaan smartphone tinggi adalah yang memiliki skor pada rentang 15-18. Skor yang berada pada rentang 11-14 termasuk kategori sedang. Adapun yang memiliki skor 7-10 memiliki tingkat penggunaan smartphone yang rendah.

Tabel 4. Intensitas penggunaan smartphone peserta diklat

\begin{tabular}{ccc}
\hline Tingkatan & Frekuensi & Prosentase \\
\hline Rendah & 34 & 32,08 \\
Sedang & 55 & 51,89 \\
Tinggi & 17 & 16,04 \\
\hline
\end{tabular}

Sumber: Olah Data Penulis, 2019

Berdasarkan tabel 4, diketahui bahwa sebagian besar peserta diklat memiliki instensitas penggunaan smartphone pada tingkat sedang yaitu dengan persentase 52\% (55 orang) kemudian 16\% (17 orang) kelompok subjek memiliki instensitas penggunaan smartphone pada kategori tinggi. Sedangkan sisanya yaitu 32\% (34 orang) kelompok subjek memiliki instensitas penggunaan smartphone pada taraf yang rendah.

Berdasarkan hasil pengolahan data diketahui bahwa rata-rata tingkat kecemasan pada kelompok subjek adalah 34.16 dengan nilai minimum 15 nilai maksimum 51 serta titik tengah 12,5 . Adapun rentang antara nilai minimum dan nilai maksimum adalah 36 Sehingga peneliti membagi tingkat kecemasan pada kelompok subjek menjadi tiga kategori yaitu: tinggi, sedang, dan rendah.

Kelompok subjek yang memiliki skor pada rentang 39-51 termasuk pada kategori tingkat kecemasan yang tinggi. Kelompok subjek yang memiliki skor pada rentang 27-38 termasuk pada dalam kategori tingkat kecemasan yang sedang. Adapun kelompok subjek dengan tingkat kecemasan pada kategori rendah adalah yang memiliki skor pada rentang 15-26. 
Tabel 4. Tingkat Kecemasan peserta diklat

\begin{tabular}{ccc}
\hline Tingkatan & Frekuensi & Prosentase \\
\hline Rendah & 22 & 20,75 \\
Sedang & 50 & 47,17 \\
Tinggi & 34 & 32,08 \\
\hline
\end{tabular}

Sumber: Olah Data Penulis, 2019

Berdasarkan tabel 5, diketahui bahwa 50 orang (47\%) peserta diklat memiliki tingkat kecemasan pada tingkat sedang kemudian 34 orang (32\%) kelompok subjek memiliki tingkat kecemasan pada kategori tinggi. Sedangkan sisanya yaitu 22 orang (21\%) kelompok subjek memiliki tingkat kecemasan pada taraf yang rendah. Hal tersebut membuktikan bahwa peserta diklat yang menjadi subjek penelitian memiliki tingkat kecemasan, meskipun dalam taraf yang berbeda.

\section{Pembahasan}

Hasil penelitian memperlihatkan hasil korelasi 0,549 dengan taraf signifikansi sebesar 0,000 yang menunjukkan bahwa terdapat hubungan positif yang sangat signifikan antara penggunaan smartphone dengan kecemasan peserta diklat. Artinya makin tinggi instensitas penggunaan smartphone maka akan makin tinggi pula tingkat kecemasannya, demikian sebaliknya makin rendah intensitas penggunaan smartphone maka akan makin rendah pula tingkat kecemasan. Tingkat kecemasan semakin meningkat dikarena semakin sering penggunanya menggunakan smartphone dalam aktivitas sehari-harinya. Hampir semua aktivitas yang dilakukan tidak terlepas dari penggunaan smartphone. Hal inilah yang menyebabkan seseorang menjadi sangat bergantung pada smartphone lebih dari sebelumnya, yang pada akhirnya akan memperburuk atau meningkatkan kecemasan yang disebabkan oleh penggunaan smartphone (Yildiirm, 2014).

Hasil penelitian ini serupa dengan yang dilaporkan Fitri Verawati Fajri (2017) membuktikan bahwa ada hubungan positif yang sangat signifikan antara penggunaan smartphone dengan nomophobia. Kontribusi efektif penggunaan smartphone terhadap nomophobia sebesar $39,2 \%$. Tingkat pengguna smartphone dan nomophobia dalam sample ini termasuk katagori tinggi.

Dalam penelitian ini di tingkat penggunaan smartphone peserta diklat berada pada katagori sedang diakibatkan karena rentang usia peserta diklat yang dijadikan responden bisa dikatakan bukan remaja (41 s.d. 50 tahun). Hasil penelitian yang ada selama ini juga lebih memfokuskan intensitas pengguna smartphone yang berakibat pada meningkatnya kecemasan banyak dilakukan dikalangan remaja. Hasil survei statistik yang di publish di databoks juga menulisakn bahwa usia terbanyak pengguna media sosial adalah usia 25 s.d. 34 tahun.

Hasil penelitian ini telah membuktikan bahwa tingkat penggunaan smartphone juga berpengaruh terhadap tingkat kecemasan pada usia dewasa. Walaupun masih dalam katagori sedang. Dan bahkan ada 32,08 \% yang sudah termasuk dalam katagori tinggi.

Hal tersebut karena saat itu peserta sedang berada jauh dari keluarganya, kecemasan menjadi meningkat saat smartphone jauh dari penggunanya terjadi karena mereka tidak bisa melakukan kontak apapun dengan orang lain (keluarga dan teman). Tidak bisa menerima kabar dan berinteraksi lewat smartphonenya, mengakses sosial media, mengakses informasi. Bahkan bis ajadi untuk saat mengikuti diklat, intensitas penggunaan smartphone semakin meningkat karena aplikasi yang mempermudah hidup seperti transportasi online, mobile banking sehingga ketiadaan smartphone akan semakin meningkatkan kecemasan penggunanya.

Hasil penelitian tentang kecemasan bahwa responden terbanyak berada pada kategori dengan tingkat kecemasan sedang (50 orang atau 47,17\%). Menurut Karim dan Abdullah (2014) Umur antara 18 hingga 24 tahun lebih nomophobik yaitu sebesar $77 \%$, sedangkan peringkat umur antara 25 hingga 34 tahun 68\% tergolong nomophobik. Dan hanya sebagian kecil golongan pekerja berumur 45 tahun dan keatas yang digolongkan sebagai golongan nomophobik. Dan responden pada penelitian ini terbanyak pada rentang usia 41-50 tahun. Kalau dilihat dari jenis kelamin responden pada penelitian ini yaitu didominasi laki-laki 84 orang (79,25\%). Karim dan abdullah melaporkan bahwa wanita (70\%) lebih risau apabila berjauhan dengan telefonnya sehingga wanita lebih rentan termasuk golongan nomophobia.

Smartphone memiliki banyak atribut dan karakteristik yang membuatnya menjadi 
menarik. Kepemilikan dan penggunaan smartphone memiliki beberapa fungsi yaitu (a) Memperkuat otonomi pribadi, khususnya yang berkaitan dengan orang tua ; (b) Menyediakan identitas dan prestise dalam konteks hubungan dengan rekan-rekan, tujuan yang cukup jelas dengan model terbaru atau paling modis; (c) Menawarkan inovasi teknologi utama, alat yang menunjukkan kecenderungan dan keterampilan khusus bagi remaja; (d) Berfungsi sebagai hiburan dan sumber kesenangan; (e) Pembentukan dan menjaga hubungan interpersonal melalui fasilitas teknologi, seperti yang mencari riyawat panggilan tak terjawab, dengan fungsi sosial dan afektif yang jelas (Chóliz, 2012).

Penelitian di Inggris tentang nomophobia menunjukkan hasil 53\% koresponden merasa cemas apabila hanphonenya hilang, low baterai, atau tidak ada sinyal (Dwi K, 2017). Penelitian serupa yang dilakukan di Amerika bahkan menunjukkan hasil yang lebih tinggi, yakni sekitar 66 persen responden yang menunjukkan nomophobia. Lebih tinggi $13 \%$ dari hasil peneliatian yang dilakukan di Inggris. Sekitar 2/3 orang Amerika tidur dengan membawa ponsel disebelahnya, dan bahkan 50\% diantaranya tidak pernah mematikan ponselnya. Lebih parah lagi, 34\% dari korespondennya menjawab bahwa mereka menjawab telepon dan bermain dengan ponselnya ditengah waktu personal bersama pasangannya (Bivin et. al dalam Fitri Verajati Fajri, 2017). Penelitian dari Institut Lowa dengan mensuiver 300 orang, memperlihatkan hasil bahwa ada 4 alasan mengapa seseorang bisa terkena nomophobia, yakni ketakutan akan kehilangan komunikasi, ketakutan kehilangan informasi, takut terputus hubungan dengan orang lain, dan ketakutab hidup susah tanpa adanya handhphone (Pavithra et.al dalam Fitri Verajati Fajri, 2017).

Dampak di bidang psikologis yang ditimbulkan akibat penggunaan smartphone yang berlebihan, individu merasa ketidak nyamanan dan rasa gelisah bila tidak bisa mengakses atau membawa smartphone. Intesitas penggunaan smartphone yang berlebihan atau terus menerus untuk komunikasi juga dapat mengganggu hubungan sosial akibat berkurangnya kontak secara fisik dalam berkomunikasi atau perasaan tidak diterima atau terpisah dari orang lain. Keuangan juga bisa terganggu karena pengeluaran untuk membayar jasa operator terkait fasilitas yang diberikan (Yuwanto, 2010).

Aktivitas terbanyak yang dilakukan peserta diklat dengan smartphonenya adalah mengakses sosial media sebanyak 60 orang $(60,48 \%)$. Hasil penelitian serupa juga dijelaskan oleh Azka, Fatih dkk (2018) dengan menggunakan responden mahaiswa, menunjukkan bahwa dalam satu hari responden dapat mengakses media sosial dari smartphone $>3$ jam, dan perlu sekitar 5 jam untuk mengakses media sosial dalam sehari. Kegiatan yang paling banyak dilakukan oleh responden di dunia maya adalah mengakses media sosial (84.2\%), browsing/searching di google (65.7\%), bermain game online $(39.2 \%)$, menonton video (38.9\%), membaca berita (31.4\%), dan mengakses e-mail (30.7\%). Mahasiswa dapat menghabiskan sebanyak 35 jam dalam seminggu untuk mengakses media sosialnya dan hanya menghabiskan rata- rata sekitar 3 jam waktunya dalam seminggu untuk belajar secara maksimal. Hal penelitian ini sungguh memprihatinkan bahwa mahasiswa lebih memprioritaskan untuk membuka social media dibandingkan membuka situs-situs yang terkait dengan pembelajaran ynag sedang mereka ikutin. Bahkan ada juga beberapa mahasiswa yang menghabiskan waktu sampai 10 jam sehari dhanya untuk bermain dengan ponselnya, dan rata- rata 184,6 menit sehari mereka gunakan untuk berinteraksi dengan teman menggunakan fasilitas chatting yang ada dismartphone mereka.

Hasil survei The Asian Parent (2021) menunjukkan, ibu di Indonesia rata-rata menghabiskan tiga jam setiap hari untuk bermedia sosial. Media sosial yang digunakan pun beragam, tetapi sebagian besar mengakses Instagram (95\%), Facebook (85\%), dan YouTube $(83 \%)$. Sebanyak $71 \%$ responden mengakses internet ketika sedang beristirahat dari pekerjaan kantor atau rumah tangga. Waktu lainnya yang sering digunakan untuk berinternet adalah sebelum tidur malam (63\%) dan setelah bangun pagi (40\%) (databoks.katadata.co.id, 2021).

Konsep nomofobia dalam psikologi klinis mengacu pada ketakutan seseorang bahwa mereka tidak akan dapat mengakses dan 
berkomunikasi dengan perangkat seluler (King et al., 2013). Individu dengan perilaku nomofobik mengalami gangguan psikososial, perilaku, dan kecemasan yang mempengaruhi kehidupan mereka ketika mereka jauh dari perangkat seluler mereka (Dixit et al., 2010). Jika frekuensi perilaku nomofobik individu meningkat, ini berdampak negatif terhadap kinerja akademik mereka, tingkat motivasi mereka dalam proses pembelajaran, dan hubungan mereka dengan keluarga dan teman sebaya.

(Erath, S. A et.al 2007) mengemukakan ada tiga aspek kecemasan yaitu ketakutan akan dinilai negatif oleh orang lain, isolasi dan penghindaran sosial orang asing dan orang yang dikenal, Dan menurut (Amanda, 1996) kecemasan memiliki 4 ciri-ciri yaitu kognitif, perilaku, respon tubuh dan perasaan. Ciri kognitif ditandai dengan mengkhawatirkan apa yang orang pikirkan, sulit untuk berkonsentrasi. Ciri perilaku meliputi tidak sabaran dan gelisah saat tidak memegang smartphone, kadang berbicara dengan cepat atau lambat. Muka merah, berkeringat, tegang, panik merupakan ciri-ciri respon tubuh. Grogi, cemas, takut terhadap sesuatu yang belum terjadi, frustasi, marah terhadap diri sendiri, merasa sedih termasuk ciri-ciri emosi atau perasaan.

Mengutip dari (Jeffrey S. Nevid, dkk 2005: 164) tentang kecemasan, makin mudah orang mengalami kecemasan seperti kecemasan akan sesuatu yang belum terjadi, kecemasan yang terlalu berlebihan dan cenderung tidak masuk akal. Contohnya perasaan seseorang yang merasa cemas jika smartphonenya tidak ada didekatnya, cemas tidak bisa berkomunikasi, takut kehilangan identitas maya, tidak nyaman karena tidak bisa mengetahui hal-hal terbaru dimedia sosial dan informasi daring lainnya, merasa "mati gaya" karena tak tahu harus berbuat apa.

Saat ini smartphone telah memegang peranan penting dalam aktivitas sehari-hari penggunanya, dengan kemampuannya atau fitur serta fasilitas yang banyak, smartphone memfasilitasi kemudahan dalam berkomunikasi, membantu seseorang tetap terhubung dengan orang lain dimana saja, kapan saja, dan memberikan kemudahan dalam mengakses informasi. Hal tersebut menyebabkan seseorang menjadi lebih bergantung dengan ponsel lebih dari sebelumnya, yang pada akhirnya akan meningkatkan kecemasan yang disebabkan oleh penggunaan smartphone yang berlebihan. Hal ini juga dikemukan oleh Yildiz, yang menjelaskan bahwa smartphone saat ini menjadi salah satu masalah yang menyebabkan perilaku ketergantungan terbesar terhadap smartphone atau yang dikenal dengan nomophobia (Yıldız Durak, 2018).

Penelitian Palupi, dkk (2018) menunjukkan bahwa kecanduan smartphone memiliki hubungan yang signifikan dengan tingkat kecemasan. Terdapat 202 responden (94,39\%) yang menggunakan smartphone $>4$ jam sehari, dan sisanya menggunakan smartphone $<4$ jam sehari yaitu sebanyak 12 orang $(5,6 \%)$. Didapatkan hasil mayoritas responden dengan ketergantungan sedang mengalami kecemasan ringan sebesar $77,9 \%$, sedangkan responden yang mengalami kecemasan sedang sebanyak $68,4 \%$. Dan responden dengan ketergantungan tinggi mengalami kecemasan ringan sebesar 11,5\% dan mengalami kecemasan sedang sebesar $26,3 \%$.

Kemudahan yang diberikan smartphone menyebabkan ketergantungan yang tinggi dikarenakan karenakan penggunanya bisa melakukan panggilan, mengirim informasi, browsing, atau melakukan kontak apapun dengan orang lain (keluarga dan teman) lewat ponselnya menyebabkan semakin tinggginya tingkat kecemasan ketika smartphone tidak ada didekatnya. Penggunaan smartphone merupakan yang berlebihan tersebutlah menjadi salah satu faktor yang mempengaruhi tingkat nomophobia.

Permasalahan sosial yang terjadi saat ini salahsatunya disebabkan karena penggunaan smartphone yang tanpa kontrol. Permasalahan tersebut diantaranya seseorang akan merasa terisolasi dari lingkungan sosialnya, timbulnya perasaan cemas yang berlebihan dan merasa tidak lengkap, atau kurang yakin jika berjauhan dengan smartphone (Dasiroh, Nurjannah, Miswatun, \& Ilah, 2015). Seseorang dengan gangguan kecemasan sering merasa gugup, cemas, berkeringat dan gemetar jika smartphone tidak ada dalam genggamannya (Ylldız Durak, 2018). 
Dalam keadaan tertentu, bagi seseorang smartphone dirasa dapat membuatnya lebih aman dan nyaman karena dapat mengurangi kegugupan. Dari hasil uji statistik terhadap hubungan penggunaan smartphone dengan kecemasan (nomophobia) hasil $p$ value $=0.000$ $(p<0,05)$ yang berarti terdapat hubungan yang signifikan penggunaan smartphone dengan tingkat kecemasan. Pada saat mengikuti diklat selama 10 hari, peserta berada jauh dari keluarganya. Smartphone menjadi penghubung peserta dengan keluarganya. Bukan cuma itu saja, tetapi peran smartphone menjadi sangat penting karena sebagai media komunikasi dan interaksi antar peserta. Hasil penelitian menjelaskan bahwa variabel kecemasan hanya dipengaruhi sebesar $30,2 \%$ oleh variabel penggunaan smartphone. Hal ini bisa terjadi karena usia peserta pelatihan yang dominan berkisar antara usia 41 s.d. 50 tahun, karena banyak hasil penelitian yang melaporkan bahwa usia terbanyak pengguna smartphone adalah 25 s.d. 34 tahun. Dan berdasarkan gender lebih banyak laki-laki yaitu $79,25 \%$ (84 orang), sementara wanita lebih rentan terkena nomophobia.

Tingkat kecemasan yang terlihat dari peserta diklat yang diakibatkan tingkat penggunaan smartphone seperti gelisah, keluar masuk kelas untuk menerima atau membuat panggilan, sering mengecek smartphone hanya untuk melihat aplikasi WA, sering mengupdate status media sosial, cemas saat smartphone tidak ada didekatnya. Bahkan saat belajar pun masih ada beberapa peserta yang "asyik" bermain dengan smartphonenya.

Selama ini fenomena nomophobia banyak ditemukan terutama pada usia remaja 18-25 tahun yang berada pada jenjang pendidikan tinggi yang berstatus mahasiswa. Menurut data dari The Royal Society For Public Health, banyak kalangan anak muda berusia dari 18-25 tahun sangat cenderung sekali mengalami nomophobia dikarenakan pada masa usia ini mereka tidak memiliki perkerjaan, hobi, atau semacam rutinitas lainya sehingga mereka lebih banyak mengahabiskan waktu dengan bermain smartphone (Aguilera-Manrique et al., 2018). Tetapi dari hasil penelitian ternyata orang dewasapun memiliki resiko untuk tingkat kecemasan yang bisa mengakibatkan nomophobia dikarena meningkatnya tingkat penggunaan smartphone.

Penelitian yang dilakukan oleh Palupi 2018 tentang hubungan ketergantungan smarthphone terhadap kecemasan mahasiswa fakultas Ponogoro juga menjelaskan hasil yang sejalan yaitu ketergantungan smartphone memiliki hubungan yang signifikan dengan tingkat kecemasan, dengan koefisien signifikasi sebesar 0,001 dan koefisien korelasi sebesar 0,260 (Pahlupi, 2018).

\section{PENUTUP}

\section{Simpulan}

a. Terdapat hubungan positif yang sangat signifikan antara penggunaan smartphone dengan kecemasan peserta diklat.

b. Tingkat penggunaan smartphone peserta diklat terbesar termasuk dalam katagori sedang.

c. Tingkat kecemasan peserta diklat terbanyak pada kategori tingkat kecemasan sedang.

\section{Rekomendasi}

Penelitian ini hanya melihat hubungan dari indikator-indikator kecemasan dengan penggunaan smartphone, karena itu perlu penelitian lanjutan untuk melihat indikator mana yang paling dominan dalam mempengaruhi kecemasan. Selain itu perlu penelitian lebih lanjut tentang faktor-faktor lain yang mempengaruhi kecemasan, seperti kontrol diri, self-esteem, tipe kepribadian, perhatian orang tua. Serta dampak lain yang mungkin ditimbulkan dari penggunaan smartphone yang berlebihan.

Untuk Pusdiklat Tenaga Teknis, hasil penelitian ini bisa jadi bahan masukan dalam membuat tata tertib atau aturan penggunaan smartphone dalam penyelenggaarn diklat khususnya saat proses pembelajaran berlangsung. 


\section{DAFTAR PUSTAKA}

Aguilera-Manrique, G., Márquez-Hernández, V. V., Alcaraz- Córdoba, T., Granados-Gámez, G., Gutiérrez-Puertas, V., \& Gutiérrez-Puertas, L. (2018). The relationship between nomophobia and the distraction associated with smartphone use among nursing students in their clinical practicum. PloS ONE. https://doi.org/10.1371/journal.pone.0202953

Akbar, R. S., Aulya, A., Psari, A. A., \& Sofia, L. (2019). Ketakutan akan kehilangan momen (FoM0) pada remaja kota Samarinda. Psikostudia J. Psikol, 7(2), 38.

Amanda, G. (1996). Social phobia: Diagnosis, assessment, and treatment. American Journal of Psychotherapy, 50(3), 373-374. doi:http://eresources.perpusnas.go.id:2102/10.1176/appi.psychotherapy.1996.50.3.373

Azka, Fatih., dkk. (2018). Kecemasan Sosial dan Ketergantungan Media Sosial pada Mahasiswa. PSYMPATHIC: Jurnal Ilmiah Psikologi Volume 5, Nomor 2, 2018: 201-210. D0I: 10.15575/psy.v5i2.3315.

Chóliz, M. (2012) 'Mobile-Phone Addiction in Adolescence: The Test of Mobile Phone Dependence (TMD).', Progress in Health Sciences, 2(1), pp. 33-44.

Dasiroh, U., Nurjannah, Miswatun, S., \& Ilah, Y. F. (2015). Fenomena Nomophobia Di Kalangan Mahasiswa (Studi Deskriptif Kualitatif Mahasiswa Univeritas Riau). Program Studi Ilmu Komunikasi Universitas Riau, Medium Jurnal Ilmiah Fakultas Ilmu Komunikasi Universitas Islam Riau Volume 6 Nomor 1 26(4), Hal. 1041-1048.

Davidson, Gerald C. (2004). Psikologi Abnormal (edisi ke 9). Jakarta: PT. Raja Grapindo Persada.

Erath, S. A., Flanagan, K. S., \& Bierman, K. L. (2007). Social anxiety and peer relations in early adolescence: Behavioral and cognitive factors. Journal of Abnormal Child Psychology, 35(3), 405-16. doi:http://eresources.perpusnas.go.id:2102/10.1007/s10802-007-9099-2

Fajri, Fitri Verawati and Lisnawati Ruhaena. (2017). Hubungan Antara Penggunaan Telepon Genggam Smartphone Dengan Nomophobia Pada Mahasiswa. Skripsi thesis, Universitas Muhammadiyah Surakarta. http://eprints.ums.ac.id/id/eprint/56457

Haug, S., Castro, R. P., Kwon, M., Filler, A., Kowatsch, T., \& Schaub, M. P. (2015). Smartphone use and smartphone addiction among young people in Switzerland. Journal of behavioral addictions, 4(4), 299307. doi:10.1556/2006.4.2015.037

Haryanto, Agus Tri, (2018). Mayoritas Orang Indonesia Bisa Akses Internet Seharian. https://inet.detik.com/cyberlife/d-3875215/mayoritas-orang-indonesia-bisa-akses-internet-seharian

Jeffrey S. Nevid, dkk. (2005). Psikologi Abnormal. Edisi Kelima. Jilid 1. Jakarta: Erlangga.

K, Dwi. (2017). Apakah Nomophobia itu? https://jurnalapps.co.id/apakah-nomophobia-itu-12621

Karim, F. H. A., Sabil, S., \& Abdullah, S. M. (2017). Nomophobia Dan Konflik Kerja-Keluarga Di Malaysia: Satu Analisis Menggunakan Structural Equation Modeling. E-bangi, 12(3), 1-19. Retrieved from https://eresources.perpusnas.go.id:2071/docview/2123025430?accountid=25704

King, A, L., Valenca, A, M., Silva, A, C., Sancassiani, F., Machado, S \& Nardi, A, E. (2014). "Nomophobia": Impact of Cell Phone Use Interfering with Symptoms and Emotions of Individuals with Panic Disorder Compared with a Control Group. Clinical Practice \& Epidemiology in Mental Health, 10. pp. 28-35.

Palupi, D. A., Sarjana, W., \& Hadiati, T. (2018). Hubungan Ketergantungan Smartphone Terhadap Kecemasan Pada Mahasiswa Fakultas Diponegoro. Jurnal Kedokteran Diponegoro, 7(1), 140-145.

Przybylski, A. K., Murayama, K., DeHan, C. R, \& Gladwell, V.(2013). Motivational, Emotional and Behavioural Correlates of Fear of Missing Out. Computer in human behavior. 29(4) : 18411848. 
Riyanto, Galuh Putri. Jumlah Pengguna Internet Indonesia 2021 Tembus 202 Juta. https://tekno.kompas.com/read/2021/02/23/16100057/jumlah-pengguna-internet-indonesia-2021tembus-202-juta. Diakses tanggal 29 Agustus 2021.

Stuart, Gail W. (2006). Buku Saku Keperawatan Jiwa. Alih Bahasa: Ramona P. Kapoh \& Egi Komara Yudha. Jakarta: EGC.

Tim Media Websindo. Indonesia Digital 2019 : Tinjauan Umum. https://websindo.com/indonesia-digital-2019tinjauan-umum/

Wahyudi, A. (2015) Indonesia Raksasa Teknologi Digital Asia, Tempo. Available at: http://www.tempo.co/read/kolom/2015/10/02/2310/indonesia-raksasateknologi-digital-asia (Accessed: 1 January 2016).

Williams, B.K. and Sawyer, S.C. 2011. “Using Information Technology: A Practical Introduction to Computers \& Communications. (9th edition)". New York: McGraw-Hill

Yildirim, C. (2014). Exploring the dimensions of nomophobia: Developing and validating a questionnaire using mixed methods research (Order No. 1567249). Available from ProQuest Dissertations \& Theses Global: The Humanities and Social Sciences Collection. (1620712596). Retrieved from https://eresources.perpusnas.go.id:2071/docview/1620712596?accountid=25704

Yıldız Durak, H. (2018). What Would You Do Without Your Smartphone? Adolescents' Social Media Usage, Locus of Control, and Loneliness as a Predictor of Nomophobia. Addicta: The Turkish Journal on Addictions, 5(3), 1-16. https://doi.org/10.15805/addicta.2018.5.2.0025

Yosepha Pusparisa. Daftar Negara Pengguna Smartphone Terbanyak, Indonesia Urutan Berapa? https://databoks.katadata.co.id/datapublish/2021/07/01/daftar-negara-pengguna-smartphoneterbanyak-indonesia-urutan-berapa. Diakses tanggal 29 Agustus 2021.

Yuwanto, L. (2010) Mobile Phone Addict. Yogyakarta: Putra Media Nusantara. 